DOI: $10.20396 /$ cel.v62i0.8658760

\title{
PLURALS IN KAIOWÁ AND THE CASE FOR OBLIGATORY IMPLICATURES
}

\author{
PLURAIS EM KAIOWÁ E O CASO DE IMPLICATURAS \\ OBRIGATÓRIAS
}

\author{
HELENA GUERRA VICENTE ${ }^{1,2}$ \\ DAIANE RAMIRES ${ }^{3}$
}

\begin{abstract}
RESUMO: O foco deste artigo é a marcação nominal opcional de número em Kaiowá (Tupí-Guaraní), expressa pela afixação, em posição pós-nominal, de -kuera, um elemento que, conforme defendemos, é um morfema que pertence ao sistema central de concordância de número da língua. Com base no exame de dados linguísticos originais, demonstramos a ampla ocorrência desse morfema na língua, que não se restringe a contextos definidos, sendo frequente também em contextos indefinidos, genéricos e com nomes que denotam espécie. Além disso, notamos em uma análise preliminar que -kuera também pode funcionar como morfema de plural associativo. De uma perspectiva teórica formal, nosso objetivo é estender aos fatos do Kaiowá uma proposta que trata a leitura "mais de um" / "pelo menos dois", expressa pela marcação manifesta do marcador de plural, como sendo derivada de uma implicatura (cf. SPECTOR 2007). Tal proposta requer que sejam levadas em consideração alternativas (cf. FĂLĂUŞ 2013) semanticamente ativadas, porém não realizadas morfologicamente. Assim, embora a função singular não esteja disponível na morfologia da língua, ela pode ser ativada na semântica como uma alternativa para uma construção em que -kuera está presente. Defendemos, portanto, que esse morfema, opcional, funciona na língua como um "ativador de alternativas" e, uma vez que uma alternativa é ativada, a implicatura escalar passa a ser obrigatória (cf. CHIERCHIA 2006). As duas leituras em competição, isto é, de plural vs. singular, constituem o conjunto de alternativas escalares que pode ser formalizado como kuera ${ }^{\mathrm{ALT}}=\{\lambda \mathrm{P}: * \mathrm{P}=\mathrm{P} . \mathrm{P}, \lambda \mathrm{P}: \mathrm{AT}(\mathrm{P})=\mathrm{P} . \mathrm{P}\}$
\end{abstract}

Palavras-chave: plural; implicaturas; alternativas.

${ }^{1}$ Universidade de Brasília, UnB, Brasília, Brasil. helenaguerravicente@hotmail.com Orcid: https://orcid.org/0000-0002-3247-2737

${ }^{2}$ This research was partially developed during the first author's visit to Harvard University (Professor Visitante no Exterior Júnior/PVEX-CAPES, 2018-2019) and the second author's master's studies at Universidade de Brasília (UnB, 2017-2019). The authors are deeply indebted to Gennaro Chierchia, Veneeta Dayal and Roberta Pires de Oliveira. We would also like to thank Ana Suelly Cabral, Marina Magalhães, Ana Müller, Shumian Ye, the anonymous reviewers from the Committee of NaP2019 (Number and Plurality: crosslinguistic variation in the nominal domain, held at GeorgAugust-Universität Göttingen) and its audience, as well as the two anonymous reviewers from Caderno de Estudos Linguísticos for their valuable comments and suggestions. All remaining errors are our responsibility. This study was financed in part by Coordenação de Aperfeiçoamento de Pessoal de Nível Superior (CAPES) - Finance code 001 (Helena Guerra Vicente) and Conselho Nacional de Desenvolvimento Científico e Tecnológico (CNPq) (Daiane Ramires).

${ }^{3}$ Universidade de Brasília, UnB, Brasília, Brasil. danny-ramires@hotmail.com

Orcid: https://orcid.org/0000-0002-0615-4460 
RESUMEN: El enfoque de este artículo es la marcación nominal opcional de número en Kaiowá (Tupí-Guaraní), expresada por la afijación, en posición post-nominal, de -kuera, un elemento que, según defendemos, es un morfema que pertenece al sistema central de concordancia de número de la lengua. Con base en el examen de datos linguísticos originales, demostramos la amplia ocurrencia de ese morfema en la lengua, que no está restringido a contextos definidos, siendo también frecuente en contextos genéricos indefinidos y con nombres que denotan especie. Además, notamos en un análisis preliminar que -kuera también puede funcionar como un morfema asociativo plural. Desde una perspectiva teórica formal, nuestro objetivo es extender a los hechos de Kaiowá una propuesta que se ocupa de la lectura "más de uno" / "al menos dos", expresada por la marcación manifiesta del marcador de plural, como derivada de una implicatura (cf. SPECTOR 2007). Dicha propuesta requiere que se tomen en cuenta las alternativas (cf. FĂLĂUŞ 2013) que se activen semánticamente, pero que no se realicen morfológicamente. Así, aunque la función singular no está disponible en la morfología de la lengua, puede activarse en la semántica como alternativa a uma construcción en la que -kuera está presente. Argumentamos, por lo tanto, que ese morfema opcional funciona en la lengua como un "activador de alternativas" y, una vez que se activa una alternativa, la implicatura escalar se vuelve obligatoria (cf. CHIERCHIA 2006). Las dos lecturas en competencia, es decir, de plural vs. singular, constituyen el conjunto de alternativas escalares que se pueden formalizar como kuera ${ }^{\mathrm{ALT}}=\{\lambda \mathrm{P}: * \mathrm{P}=$ P.P, $\lambda$ P: AT $(\mathrm{P})=$ P.P $\}$

Palabras-clave: plural; implicaturas; alternativas.

\section{INTRODUCTION}

Kaiowá, a language belonging to the Tupí-Guaraní language family, subgroup I, Tupí stock (RODRIGUES 1985), is spoken by approximately 30,000 people in the south of the state of Mato Grosso do Sul and in parts of Paraguay. Kaiowá is still acquired as a native language, and, according to Mejia (2017), who cites data from Unesco, Kaiowá is not in the process of extinction, though it is considered vulnerable.

The objective of the present article is to analyze the nominal phrase in Kaiowá and, in particular, the expression of number in this language. Kaiowá is a language without articles which allows bare nominals. ${ }^{4}$ Moreover, the language makes use of an optional plural marker (-kuera), whose absence does not necessarily express singularity. Given that the bare nominal is ambiguous/neutral as regards the expression of number and (in)definiteness, the strategies utilized by the speaker as regards the expression of number and (in)definiteness vary between (i) the expression of an "undifferentiated denotation" (cf. MÜLLER et al. 2006, for Karitiana, a language that does not even possess optional markers) for number and (in)definiteness, in which the singular-plural and definite-indefinite

${ }^{4}$ It is important to note, however, that bare nominals are not restricted to languages that lack articles. Brazilian Portuguese, for example, is a language which possesses definite and indefinite articles, and which nonetheless permits bare nominals, including both bare singulars and bare plurals (MÜLLER, 2002; MÜLLER \& OLIVEIRA, 2004; PIRES DE OLIVEIRA \& ROTHSTEIN, 2011; CYRINO \& ESPINAL, 2014, among others). For a typological characterization of languages that have, and languages that lack, (in)definite articles, we refer the reader to the map in chapter 38 (DRYER 2013), of the The World Atlas of Language Structures Online (see the complete reference at the end of the present article). It bears making note of certain typological similarities between Portuguese and Kaiowá: (i) pronominal demonstratives and nominal quantifiers appear pre-nominally and (ii) adjectives appear post-nominally. However, in contrast to Portuguese, Kaiowá has postpositions, rather than prepositions, as will be seen in the glosses presented in the course of the present study. 
distinctions are simply irrelevant, (ii) a dependency upon the situational context in which the utterance is spoken, and (iii) a syntactico-semantic dependency, forcing one interpretation or another, that is, singular vs. plural, and definite vs. indefinite. In this work, we will concentrate on strategy (iii), since our aim is to verify the productivity/occurrence of -kuera in contexts which force either definite or indefinite readings.

Most of the Kaiowá data in this paper are original and, unless otherwise stated, were collected by this paper's two authors throughout the two-year-andtwo-month period (April 2017- June 2019) of the second author's ${ }^{5}$ master's studies at Universidade de Brasília (UnB), which resulted in an MA thesis on the expression of number and (in)definiteness in Kaiowá, written under the first author's supervision. The questionnaire Identifying (in)definiteness: $a$ questionnaire (Dayal, in press), ${ }^{6}$ devised in order to diagnose (in)definiteness in languages without articles, was used as an aid to the data collection, which consisted in the elicitation of data by means of translation ("Daiane, how do you say X in Kaiowá?"), grammaticality judgment tasks ("Daiane, can you say X in Kaiowá?") and introspection. The creation of scenarios involved verbalization ("Now, Daiane, imagine there's a group of women gathered at school...") and/or drawings. The present work is an attempt to deepen issues that were introduced in Ramires's (2019) thesis, but which remained unaccounted for, such as a formal account of the singular/plural distinction in the language, which, we argue, can be explained by means of implicature and alternative-based approaches.

Although the focus of the present study is number, we will see that it is impossible to deal with this subject without mentioning (in)definiteness, since in many languages with optional plural marking, the plural marker may only affix to definite nouns. We will show that this is not the case in Kaiowá, given that the distribution of its optional plural marker is broader than in other languages in which (apparent) optional number marking is found (e.g. Japanese -tachi, Mandarin -men, Guajá -kéra and Tapirapé -kwera (both Tupian languages) and Wapishana (Arawak) -nau). ${ }^{7}$

Among researchers of South American native languages, the division of these languages into the following two groups seems to be well-established: (i) languages that do not exhibit nominal number morphology at all (e.g. Karitiana (Tupí-Arikém) (DORON; MÜLLER 2014) and (ii) languages that exhibit optional nominal number morphology (e.g. Kaiowá (Tupí-Guaraní) (RAMIRES; GUERRA VICENTE, 2018; RAMIRES, 2019), Terena (Arawak) (BUTLER, 2003; SANCHEZ-MENDES et al., 2020), Guajá (Tupí-Guaraní) (MAGALHÃES, 2008),

\footnotetext{
${ }^{5}$ A native speaker of Kaiowá, born and raised at Taquaperi reservation, in Coronel Sapucaia, Mato Grosso do Sul state.

${ }^{6}$ Examples (3), (4), (5), (6), (13) and (15) were specifically elicited with the aid of the questionnaire.

${ }^{7}$ There is only one study of Kaiowá (CARVALHO 2017) that restricts the occurrence of the optional plural marker (-kuera) to definite contexts (or, in Carvalho's terms, to "non-generic" contexts). Nevertheless, one should not discount the possibility of there being linguistic variation between Kaiowá speakers from different villages.
} 
Tapirapé (Tupí-Guaraní) (PRAÇA, 2007), Wapishana (Arawak) (SANTOS, 2006; GUERRA VICENTE et al. 2020), in which the triggers for such morphological marking may vary from language to language. ${ }^{8}$ The novelty of our study lies in the theoretical approach we have taken in accounting for the Kaiowá facts. As far as we know, an analysis which combines alternative semantics and an implicaturebased model to pluralization in order to explain the expression of plurality in a Brazilian indigenous language has not yet been carried out.

In a nutshell, the aim of this work is twofold: (i) to extend an implicaturebased approach to pluralization (see for instance SPECTOR 2007) in Kaiowá (and hopefully in other South American languages, Tupian or not) and (ii) to argue that this approach demands considering alternatives (cf. FĂLĂUŞ 2013) that are semantically activated without being morphologically realized. In order to achieve our aims, we assume that (i) -kuera is an alternative activator and, once an alternative is activated, scalar implicatures are obligatory (cf. CHIERCHIA 2006); (ii) although the singular function is not morphologically available in the language, it can be semantically activated as an alternative of -kuera; (iii) the 'more-than-one'/ 'at-least-two' readings (cf. Spector, 2007) of the overt plural marker are derived from the singular alternative reading (with only singularities in the extension).

This paper is organized as follows: in section 1, we present the Kaiowá noun phrase with particular attention on the absence of articles or obligatory plural marking. An in-depth presentation of constructions that force either definite or indefinite readings is necessary in order to demonstrate that the occurrence of -kuera, despite being optional, is virtually unconstrained. The present study adopts a universalist framework, which will be discussed in section 2. In section 3 , we explore the semantic/pragmatic notions of implicature and alternatives, both crucial to our study. In section 4, we present -kuera as an "alternative activator". The notion of implicature is developed and formalized in terms of a neo-Gricean view of alternatives (FĂLĂUŞ 2013), which takes into consideration linguistic forms not chosen by the speaker in a particular interaction. In section 5 , entitled

${ }^{8}$ Obviously, this generalization is a simplification of the variety of strategies available to mark plurality in these languages. According to Alves (2004:48), in Canela Apãniekrá (Jê), for instance, the plural marker me-can only be affixed to [+human] nouns, and its absence necessarily denotes singularity. On the other hand, plural marking in [-human] nouns relies on a different strategy, external to the noun phrase (where PR stands for "relational prefix"):

(i) + human: me

me $=$ humre

$\mathrm{PL}=\operatorname{man}$

'men'

(ii) - human: jàhto

ken j-àhto

stone PR-be.a lot

'stones' 
"Some loose ends and perspectives", we present empirical evidence that leads us to tentatively conclude that there is at least one environment in which the occurrence of -kuera seems to be obligatory: constructions that denote associative plurals. Finally, in section 6, we present our concluding remarks.

\section{THE KAIOWÁ NOUN PHRASE}

\subsection{Kaiowá, an article-less language}

With respect to the structure of its noun phrases, Kaiowá (and other indigenous Brazilian languages in general) is a language that lacks both definite and indefinite articles. From a semantic perspective, the literature on bare nominal languages tends to describe such languages as "neutral" (cf. MÜLLER et al. 2006, on Karitiana) 9 or "ambiguous" (cf. DAYAL 2004, on Hindi, Chinese, and Russian) in relation to the expression of (in)definiteness. Another important characteristic of the Kaiowá noun phrase concerns the singular/plural distinction. The basic form of the noun, which lacks inflectional marking, can, depending on the context and the speaker's intentions, express either singular or plural, and is thus "neutral" or "ambiguous" for number. Thus, the sentence in (1) can be translated in four different ways: ${ }^{10}$

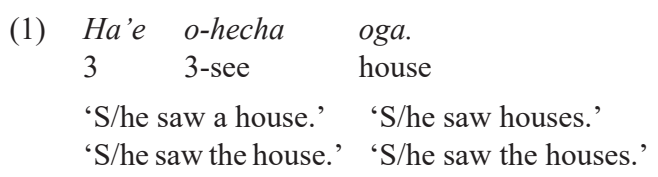

Despite lacking definite and indefinite articles, Kaiowá, on the other hand, contains a variety of pronominal demonstratives. According to Dayal (in press) (but see also Lyons 1999), definite articles are thought to have evolved diachronically from demonstrative pronouns. She claims that most, if not all, languages have demonstratives, though many lack definite and/or indefinite articles. Consider the following examples, containing the proximal demonstratives pea and koa, both meaning 'this' ${ }^{11}$ and the distal one amoa 'that':

9 MÜLLER et al. (2006:187-189) also use the expressions "cumulative denotation" and "undifferentiated denotation" in order to refer to the expression of singular/plural and (in)definiteness in Karitiana.

${ }^{10}$ So as to render the glosses more compact and legible, we will include only those morphological details that are most relevant to the point at hand. List of abbreviations: $1=$ first person singular/plural prefix; $1 \mathrm{SG}=$ first person singular; $3=$ third person singular/plural prefix; CIRC $=$ circumstantial; Compl = completive; $\mathrm{Cp}=$ comparative; INDEF = indefinite; $\mathrm{LOC}=$ locative; Neg = negation; Pas = past; $\mathrm{PL}=$ plural; $\mathrm{POST}=$ postposition; $\mathrm{Rec}=$ reciprocal; TOTAL $=$ totalitive.

${ }^{11}$ Kaiowá has two proximal demonstrative pronouns: pea and koa. The former is used with objects that are quite close to the speaker - specifically, within touching-distance of the speaker. The latter is used with objects that are close to the speaker, but not within touching-distance. 
(2)
a. $C h$
a-hecha
pea
kuatia haypyre
yvy-pe.
1SG 1-see this
paper.written.by.someone
floor-Loc

'I saw this/these book(s) on the floor.'

$\begin{array}{lllll}\text { b. Che a-hecha } & \text { koa } & \text { kuatia haypyre } & \text { yvy-pe. } \\ \text { 1SG } & 1 \text {-see } & \text { this } & \text { paper.written.by.someone } & \text { floor-Loc }\end{array}$

'I saw this/these book(s) on the floor.'

$\begin{array}{llll}\text { c. Che a-hecha amoa kuatia haypyre } & \text { yvy-pe. } \\ \text { 1SG 1-see } & \text { that } & \text { paper.written.by.someone } & \text { floor-Loc }\end{array}$

'I saw that/those book(s) on the floor.'

This being so, in order to establish with confidence that Kaiowá is an articleless language, it is necessary to prove that the demonstratives in this language cannot function as definite articles. The test below demonstrates that the word kuarahy 'sun' and the demonstrative koa 'that' are semantically incompatible:

(3) a. \# Koa kuarahy hendy verá ko'anga.
that sun
shine
today

'The sun is shining today.'

The semantic incompatibility stems from the fact that the noun kuarahy refers to a unique entity and hence cannot be accompanied by demonstratives, which are expected to have an anti-uniqueness implicature. The presence of koa 'that' in the example above necessarily triggers an anti-uniqueness implicature, which makes the example sound odd.

On the other hand, note that the numeral peter 'one' can, with certain restrictions, function as an indefinite article:

(4) O-iko va'e-kue ø/petei $\quad$ kunã hérava Mani.
3-exist time-Pas a/one woman called Mani
'Once upon a time, there was a woman called Mani.'

(Mandi'o oiko hagua 'The Legend of the Yuca', MATO GROSSO DO SUL 2002)

This example forces an indefinite interpretation, since the sentence introduces a new referent into the discourse, that is, "a woman", whom we are hearing about for the first time. Following Dayal (in press) (but see also Givón 1976), storytelling contexts are useful in testing whether bare nominals may or may not introduce a new referent, given that such contexts ensure that the speaker and hearer do not share the relevant background knowledge. Indeed, it seems to be a common property of languages for the numeral and the indefinite article to be 
homophonous. ${ }^{12}$ This is precisely what happens in Portuguese and other Romance languages.$^{13}$ As for Kaiowá, however, the alternation is between the absence of the article and the presence of the numeral. Nevertheless, tests with negation show that pete $\tilde{\imath}$ 'one' is not an indefinite in the narrow sense:

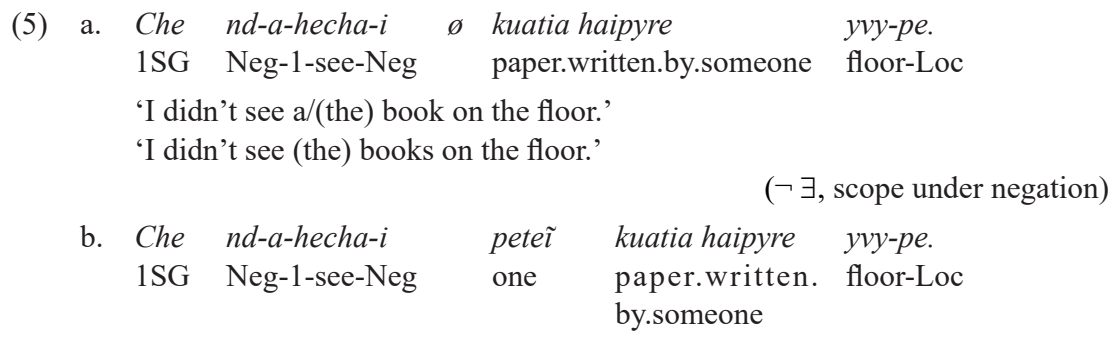

'I didn't see one book on the floor.'

$(\exists \neg$, scope over negation)

(5a) is compatible with a situation in which no book was seen on the floor. (5b), on the other hand, is compatible with a situation in which there is a book that was not seen, though other books may have been seen. The following test furnishes additional evidence for the hypothesis that we are not dealing with a true indefinite:

$\begin{array}{ccc}\text { (6) a. } \varnothing \quad \text { Vaka } \quad \text { o-karu } & \text { kapi'ire. } \\ \text { cow } & \text { 3-eat } & \text { grass } \\ \text { 'A cow eats grass.' } & \\ \text { 'Cows eat grass.' } & \\ & \text { (But also 'The cow eats grass' and 'The cows eat grass.') }\end{array}$

${ }^{12}$ In the chapter on indefiniteness in the World Atlas of Language Structures Online (DRYER, 2013), the map that illustrates the properties of indefinite articles distinguishes five types of languages: (i) languages that possess an indefinite word that is distinct from the numeral corresponding to "one" (102 languages), such as is the case in English (a house/one house); (ii) languages in which the numeral corresponding to "one" is used as the indefinite article (112 languages), such as is the case in Portuguese and other Romance languages; (iii) languages in which an indefinite affix can be affixed to nouns (24 languages); (iv) languages which lack an indefinite article, but which possess a definite article (98 languages) and (v) languages which have neither an indefinite article nor a definite article (198 languages). Kaiowá is not considered in the Atlas, but we venture that it is an instance of the fifth type of language. Kamaiurá, another member of the Tupí-Guaraní family, is classified as belonging to this same language type. We have not yet sought to establish what the alternation between $ø$ and petei 'one' is due to, nor whether this alternation is found in other languages of the Tupí-Guaraní family.

${ }^{13}$ To our knowledge, this property was originally accounted for by Givón (1981). This author lists a variety of languages, including Romance and various Amerindian and Austronesian languages, in which the numeral corresponding to 'one' can function as an indefinite article. In Givón (1981) he describes a change which Israeli Hebrew has been undergoing, in which the phenomenon in question would be allowed in its "least-formal native-speaker dialect", which he refers to as "Street Hebrew", yet "unrecognized by traditional grammarians" (1981:35). 


b. \# $\begin{array}{llll}\text { Petei } & \text { vaka } & \text { o-karu } & \text { kapi'ire } \\ \text { one } & \text { cow } & \text { 3-eat } & \text { grass }\end{array}$

\# 'One cow eats grass.'

As can be noted, a generic interpretation is possible when the numeral petei is absent, but not when it is present. (6b) is not structurally ill-formed, but odd under the intended reading (the generic reading). Here, the use of petei would only be allowed in a very particular context: for example, one in which there are a number of cows on a given farm and only one of them eats grass, with the rest of them eating cow food.

\subsection{About -kuera: morphosyntactic and semantic properties}

Classifying-kuera as a 'plural morpheme' is not uncontroversial. This element has been classified as a 'plural particle' (CARDOSO 2008:41), a 'plural suffix/ optional plural marking morpheme' (DIETRICH 2011:13-14), a 'collectivizing morpheme' (VIEGAS 2017:45), or simply a 'collective' (CARVALHO 2017:29; MEJIA 2017:78). What all these analyses have in common is the assumption that -kuera is a functional element, not a lexical element. ${ }^{14}$ This can be observed in (7), in which the lexical word aty 'group', and -kuera can cooccur, thus showing they are not mutually exclusive:
ø/Peteĩ aty a/one group
kunã (-guera/-kuera)
o-nembo-aty
3-Rec-gather
mbo'eroy-pe.
teach-Loc

'A/One group of women gathered at school.'

As we can see, there is controversy over its morphological status - whether it should be classified as a morpheme or a particle ${ }^{15}$ - and over its semantic status whether it should be classified as an ordinary plural marker or a collectivizer (also known in the literature as an "associative plural marker").

${ }^{14}$ Although according to Marina Magalhães (p.c.) it may have evolved from a lexical word meaning 'group' or something similar to it.

${ }^{15}$ In response to a question by one reviewer concerning whether particles can be classified as a type of morpheme, our response is: not necessarily. A recent publication dedicated entirely to the topic of particles - Dossier Particles (2019) - considers various analyses of these elements and ultimately proposes the existence of a continuum, with the possibility of classifying particles as 'a type of morpheme with unique properties' at one extreme of the continuum, and the possibility of treating particles as belonging to a distinct class, i.e., a 'class of particles', at the other end of the continuum. Chacon (2019), for example, classifies particles in Kubeo (Tukáno) as "a unique type of morpheme"; for Queixalós (2019), particles in Sikuani (Guahibo) belong to a class that is in between prototypical morphemes and lexical morphemes; finally, for Magalhães (2019) and Gomes (2019), these elements, in Guajá (Tupí-Guaraní) and in Mundurukú (Tupí-Guaraní), respectively, are analyzed as belonging to a "class of particles" distinct from the morpheme class. Although these analyses arrive at distinct conclusions, there is consensus that it is necessary to analyze particles as a "special" class distinct from the traditional notion of morpheme. A further conclusion reached by the authors who contributed to this publication is that it is necessary in each language to establish the criteria that differentiate particles from other linguistic elements. 
Magalhães (2008:148) and Praça (2007:61), who analyze Guajá (TupíGuaraní) and Tapirapé (Tupí-Guaraní) respectively, reach similar conclusions: namely, that these optional elements, glossed respectively as COL (collectivizer) and GRUP (grouper), ought to be considered morphemes, given their fixed postnominal position and the fact that they exhibit allomorphy, as illustrated by the boldfaced data below: ${ }^{16,17}$

\section{(8) Guajá $^{18}$}

a. Awá-wanihã-kér-a i-mymýr-a 0-pyhý wy

Guajá-man-COL-N R2-child-N 3-get PLU

'A group of Guajá men got their children.'

b. Terewé 0-memer-ér-a

cockroach R1-child-COL-N

'A group of baby cockroaches.'

(9) Tapirapé19

a. Koxy-wer-a ke i-'ew marãxi-Ø r-e woman-GRUP-REFER DUB 3.II-like watermelon-REFER R-POS

'It seems that the women like watermelon.'

b. Akoma'e-kwer-a man-GRUP-REFER $a-a \quad i-a \tilde{p} y-w o \quad k a-\varnothing$

3.I-go 3.II-burn-GER farm-REFER

'The men are going to burn the farm.'

Following this reasoning, in order to classify -kuera as a morpheme, not a particle, we will rely on the following pieces of evidence:

${ }^{16}$ But note that whereas the former author translated the structure in question as "a group of X", the latter author used plural morphology to translate it. As such, it would appear that the precise semantic contribution of this element is an open question. Indeed, the semantic contribution of this element constitutes a puzzle that permeates the study of all of these languages. In any event, the criteria in (10) have been used to establish the distinction between morphemes and other linguistic material in Tupian languages.

${ }^{17}$ Guajá data taken from Magalhães (2008:148). Tapirapé data taken from Praça (2007:61).

${ }^{18}$ List of abbreviations: $3=$ third person singular/plural prefix; $\mathrm{COL}=$ collectivizer; $\mathrm{N}=$ noun suffix; PLU = pluralizer; R1 = relational prefix $1 ; \mathrm{R} 2=$ relational prefix 2 .

${ }^{19}$ List of abbreviations: I = series I marker; II = series II marker; 3 = third person singular/plural prefix; DUB = dubitative; GER = gerund; GRUP = grouper; $\mathrm{POS}=$ postposition; $\mathrm{R}=$ relational prefix; REFER $=$ referentializer. 
(i) It has a fixed position: when it occurs, it is always affixed in post-nominal position.

(ii) It displays allomorphy: when it occurs after nasal sounds, it can be pronounced as -guera (see (7) above). ${ }^{20}$

Kaiowá is similar to other languages without articles, such as Hindi and Russian (cf. DAYAL 2004), in that it possesses number marking on nominals: -kuera, a marker which is also present, with some variation, in other Tupí-Guaraní languages. However, in Kaiowá, as opposed to Hindi and Russian, this morpheme is optional. This being the case, in a sentence like (11), -kuera may be present, but if it is, only the plural readings obtain:
(11) Kaiowá
Che a-hecha kuatia haipyre
-kuera ${ }^{21} \quad$ yvy-pe.
1SG 1-see paper.written.by.someone
-PL floor-Loc
'I saw books on the floor.'
'I saw the books on the floor.'

In this sense, Kaiowá is similar to languages like Mandarin and Japanese, among others, which possess this kind of optional plural marker, whose absence does not necessarily convey singularity (but when it occurs, it necessarily expresses plurality). However, given -kuera's morphosyntactic and semantic properties, which will become more clear throughout this paper, our proposal is that this optional morpheme belongs to the core number system of the language, since its distribution is broader than in other languages where optional number marking is found. ${ }^{22}$ The following examples illustrate the fact that the occurrence of -kuera is not restricted to definite contexts:

\section{Indefiniteness: introducing referents}

$\begin{array}{llllll}\text { Che } & a-h a & \varnothing & \text { /petei vy'aha-pe ha upe-pe } \\ \text { 1SG 1-go } \varnothing \text { one party-Loc and there-Loc }\end{array}$

$\begin{array}{llll}\text { a-hecha } & \text { hente(-kuera) } & \text { iñambu'eva } & \text { tekoha-pe-gua-kuera } \\ \text { 1-see } & \text { person-PL } & \text { different } & \text { place.to.live-Loc-Circ-PL }\end{array}$

'I went to a/the party, and there I saw people from different reservations.'

${ }^{20}$ According to Magalhães (p.c.), by hypothesis, this morphophonological effect provides additional evidence for the dependent nature of these morphemes, which should be contrasted with what is observed in connection to particles in these languages, which exhibit a more independent status.

${ }^{21}$ kuera is optional. We have removed the parentheses, which indicate optionality, for the purpose of the present example.

${ }^{22}$ In Mandarin, for instance, the optional plural marker -men can only refer to human (or humanlike) beings and shows up exclusively in definite and generic contexts (cf. JIANG 2017). 
(13)

Indefiniteness: verbs of destruction

Che sy o-pyta o-juka anguja(-kuera) o-joapygueri

1SG mother 3-keep 3-kill mouse(-PL) 3-one.after.the.other

upe araroype.

that winter

'My mother kept killing mice repeatedly that winter.'

(14) Generic statemens

$\begin{array}{llllll}\text { Mitã kunã(-kuera) } & \text { o-kaguaha pyahe mitã } & \text { kuimba'e(-kuera) } & \text { gui } \\ \text { child woman(-PL) } & \text { 3-grow } & \text { fast } & \text { child } & \text { man-PL } & \mathrm{Cp}\end{array}$

'Girls grow faster than boys.'

(15)

\section{Reference to kinds}

Kaguare(-kuera) ha'e(-kuera) mymba o-pa-tama.

anteater(-PL) 3(-PL) animal 3-Compl-end

'Anteaters are extinct.'

In (12), although there might be the possibility of shared knowledge among the participants in the interaction and the hearer may know exactly to what party the speaker is referring (hence the fact that $v y$ 'aha 'festa' can be glossed either as 'a party' or 'the party'), hente(-kuera) iñambu'eva tekoha-pe-gua-kuera 'people from different reservations', on the other hand, could never receive a definite reading, as the available information refers to a variety of people whose identities are most certainly unknown to the hearer - and perhaps even to the speaker, who even if $\mathrm{s} / \mathrm{he}$ has not been introduced to all of the people, can assume that they originate from different villages on the basis of their physical appearance, attire, etc. By contrast, a possible continuation of this narrative would necessarily demand an expression with a definite reading (such as "the people were well dressed" etc.), as the participants of the event have now been introduced into the discourse. The construction in (13) ought to force an indefinite, and necessarily plural, interpretation. Otherwise, we would have to imagine a context in which the mother repeatedly kills a rat/the same rat (the indefinite and the definite reading, respectively) or the same rats (the definite plural reading), which is impossible to do, unless we imagine a world in which it is possible to resuscitate rats so as to then be able to kill them once again. As can be noted, -kuera is likewise possible in other non-definite contexts, such as generic statements, which, according to Lyons (1999, p. 179-180), consist of noun phrases "used to express generalizations about a class as a whole", and which allow exceptions to the generalization, as these constructions "express general tendencies". The sentence in (14), for instance, expresses the belief (whether based on scientific evidence or not) that girls develop (physically and/or psychologically) more quickly than boys. The sentence 
in (15) illustrates the fact that -kuera is also allowed in constructions which make reference to 'kinds', roughly, "those generics which treat the class as a unit [and] can occur with punctual aspect" (Lyons, 1999, p. 180), though here -kuera permits fewer exceptions (or, indeed, no exception, as is the case when it occurs with an extinction verb) than it does in (14). The idea that kinds must be thought of as being like abstract individuals dates back to Carlson (1980).

Returning to the expression of number in Kaiowá: as we have seen, even though Kaiowá lacks obligatory number marking, it exhibits an optional plural morpheme, -kuera, which is affixed post-nominally. The absence of -kuera does not necessarily convey singularity, so the fact that the plural implicature takes place in the presence of a bare noun that appears to be fully amenable to plural interpretations is particularly interesting and puzzling. How is this possible? Our proposal is simple. The paradigm we are facing forces us to assume that the bare noun in Kaiowá is number neutral, ${ }^{23}$ i.e. underspecified for number, blind to the singular/plural distinction. At the same time, the singular reading must be active in the grammar of this language and act as an alternative, i.e., a competitor, to -kuera-marked nominals. This argument, which is grounded upon the semantics of alternatives, will be developed in section 3 .

\section{UNIVERSAL GRAMMAR AND CROSS-LINGUISTIC VARIATION}

Generative grammar, introduced by Chomsky in the mid-20th century, posits the existence of a Universal Grammar, a system of rigid principles that assigns the same underlying grammar to all natural languages. According to this theory, this system, which is genetically determined, corresponds to the so-called "initial state" $\left(\mathrm{S}^{0}\right)$, in which the parameters, understood as the points of cross-linguistic variation, are unvalued. The process of parameter valuation, set by the speaker's exposure to linguistic data (the input), produces a sequence of states $\left(S^{1}, S^{2} \ldots S^{n}\right)$, "reaching a relatively stable ready state that undergoes little subsequent change, apart from the lexicon" (CHOMSKY; LASNIK (1995) [1993]:14). According to the logic of this theory, then, each language is the result of (i) the interaction of the initial state and (ii) the exposure to the linguistic input. The apparent contradiction of a universal underlying grammar, which is common to all of humankind, and a variety of (apparently) different languages is resolved by the Principles and Parameters model, in which the earlier generative model grounded on the existence of language- and construction-specific rules is rejected (CHOMSKY 1998).

In this article, we are particularly interested in two parameters: (i) the parameter governing plural marking (i.e., the presence vs. the absence of such

${ }^{23}$ According to Chierchia (2010), number-neutral languages lack obligatory marking of number; moreover, they lack an obligatory system of markers. A further characteristic of these languages is that the mass vs. count distinction is found in the syntax of numerals, as these combine only with count nouns. It is paramount that the reader bear in mind throughout this paper that we are not arguing that Kaiowá is a number-neutral language; our claim is that only the unmarked nominal base forms (i.e., kuera-less nouns) in this language are number-neutral. 
formal marking, and also its optionality), and (ii) the parameter governing the formal marking of (in)definiteness (i.e., its presence vs. its absence). With regard to cross-linguistic variation, we assume Chomsky's position (2004 [2001]) that such variation is restricted to the lexicon and to the phonological component of the speaker's grammar. The semantic component and the syntactic component are uniform, which amounts to the claims that (i) if a given meaning can be expressed in a given language, then so too can that meaning be expressed in all other languages and (ii) the syntactic operations that occur in one language (Merge, Move, checking/valuation/copy and deletion of features, etc. (cf. CHOMSKY 1995 and subsequent work) can occur in all other languages. Chomsky's position can be summarized as follows:

(16) $\Sigma$ is assumed to be uniform for all L; NS is as well, if parameters can be restricted to LEX; $\Phi$, in contrast, is highly variable among Ls.

(CHOMSKY 2004 [2001]:107)

Where L is 'a possible I-language', $\Sigma$ is the 'semantic component', NS is the 'narrow syntax', LEX is the 'lexicon', and $\Phi$ is the 'phonological component'. In generative theory, an I-language corresponds to the grammatical knowledge that the speaker of a language has accumulated - that is, it corresponds to his/ her 'competence' - whereas the E-language corresponds to his/her use of this knowledge, that is, to performance. As one of the aims of this theory is to identify the underlying structure common to all languages, the study of a given language cannot be restricted to a description of its use. It must concentrate on competence, which is abstract and concerns all that is possible and all that is impossible in a given language. As such, generative theoreticians often work with negative evidence, that is, with 'ungrammatical' data (indicated by '*'), 'degraded' data (indicated by '?' or '??'), or semantically 'inadequate', 'odd' data (indicated by '\#'), since such data may reveal important information about the language under study.

Von Fintel \& Matthewson (2008), who are proponents of a framework with semantic universals, make an important caveat with respect to this model: it should eschew an anglocentric framework for natural languages, the reason being that discoveries may come from the "opposite direction"; in other words, a phenomenon studied in an under-represented language may shed light on a poorly understood phenomenon in a widely studied language, such as English. For instance, there is a study by Matthewson (2001) in which the quantificational system of St'át'imcets (Lillooet Salish) is shown to furnish new understanding of the English quantificational system. We therefore believe that the study of a bare nominal language such as Kaiowá, an understudied language, may bring new insight to the study of languages like Brazilian Portuguese, for example, which likewise allows bare singular nouns to express pluralities. ${ }^{24}$

${ }^{24}$ A study of the expression of number in Brazilian Portuguese is not within the scope of this paper, but we are familiar with at least one paper on Brazilian Portuguese (compared to English) (PIRES DE OLIVEIRA, 2019) which relies on the claim that, semantically, the plural is weak and therefore the 'at-least-two' reading must be derived as an implicature, a conclusion we adopt here as well. 
It is also important to highlight that "number neutrality" does not entail that the conceptual distinction between singular and plural is unavailable. Doron \& Müller (2014), for instance, bring evidence for a conceptual distinction of countability in Karitiana (Tupí-Arikém), which is expressed "without the mediation of morphological marking of count nouns" (p. 9). Karitiana does not have nominal number marking nor does it formally distinguish count from mass, though it does semantically distinguish nouns which can be counted from nouns which cannot.

Our proposal is that -kuera is an overt manifestation that the singular/plural distinction is active in the grammar of Kaiowá, even though the language lacks a dedicated singular, morphological form that would compete with it. Such a proposal is possible within a model that makes use of alternatives, i.e., a model in which the speaker selects a particular linguistic form from a list of possible alternatives, and this act of selecting one form over another is in itself a pertinent source of information.

\section{IMPLICATURES AND ALTERNATIVES: A GRAMMATICAL APPROACH}

In this article, we will examine implicatures under the lens of alternative semantics, by assuming that the plurality inference is a scalar implicature (Spector 2007). The term "implicature" was introduced by the philosopher of language Paul Grice in 1975 to refer to the expression of communicative intentions that are not overtly expressed by the speaker. According to Grice's model, the speaker and hearer act in a collaborative manner, in accordance with four conversational principles or "conversational maxims", which are known in the literature as "Grice's Maxims". ${ }^{25}$ Within the Gricean tradition, implicatures are considered an exclusively pragmatic phenomenon:

In the tradition stemming from Grice (1989), implicatures are considered a wholly pragmatic phenomenon [...]. Within such a tradition, semantics is taken to deal with the compositional construction of sentence meaning [...], while pragmatics deals with how sentence meaning is actually put to use [...]. Simply put, on this view pragmatics takes place at the level of complete utterances and pragmatic enrichments are a root phenomenon (something that happens globally to sentences) rather than a compositional one (CHIERCHIA et al. 2012: 2297).

In this study, we adopt a "neo-Gricean" version of the phenomenon, refined by the argument in Chierchia $(2004,2006)$ and Chierchia et al. (2012) that implicatures (more specifically, scalar implicatures) should be derived in the grammar, and not in pragmatics, (or "post-grammatically"). According to this logic, the traditional division of labor between semantics and pragmatics (i.e., a compositional/post-compositional distinction) should therefore be reassessed and reformulated, given that

\footnotetext{
${ }^{25}$ These are the relation, quantity, quality and manner maxims (cf. GRICE 1975:45-46).
} 
[...] certain pragmatic processes (i.e., processes involving the speaker's intentions and other aspects of the conceptual/intentional system) are visible to (and accessed by) the computational system, More specifically, (some) implicatures are computed recursively and compositionally, on a par with ordinary meaning computation (and therefore are not part of a postgrammatical process (CHIERCHIA 2006:544, emphasis added).

The spirit of Grice's seminal proposal is nonetheless maintained in the assumption that the selection of one communicative option over another is in itself informative. This array of communicative options is what the literature has termed "alternatives". ${ }^{26}$

Assuming it is not possible to derive scalar implicatures in their full strength by logic alone, as Grice would seek to do (cf. SAUERLAND 2004; CHIERCHIA et al. 2012), how should these be calculated under this grammatical, neo-Gricean approach? According to this model, which derives from Horn's seminal work, ${ }^{27}$ alternatives can be computed in grammar by means of a covert, grammatical exhaustification mechanism, which, in this framework, corresponds to the insertion of a silent operator modeled on the semantics of 'only', usually referred to as EXH or $O$ (CHIERCHIA 2004; SPECTOR 2007; FĂLĂUŞ 2013, among others). Such grammatical device should restrict, by specifying lexical scales, a set of alternatives that is, in turn, generated by UG principles through independent recursive computational processes, and "this is part of what makes sentence meaning multidimensional" (CHIERCHIA et al. 2012:2299).

Fălăuş explains that

In alternative-based theories of questions and focus, alternatives are obligatorily computed. Implicatures on the other hand, and hence the alternatives on which they are based, are not obligatory. Alternatives are activated only if relevant in a given context and if their computation leads to meaning enrichment (a result obtained by excluding any alternative stronger than the assertion) (FĂLĂUŞ 2013:20, emphasis added).

${ }^{26}$ The first studies of alternatives - that is, semantics based on alternatives -, date back to the 1970s, with the studies of Horn (1972) and Gazdar (1979) on scalar implicatures. Fălăuş (2013) points out that although this theory has been most systematically established in connection with the phenomena of implicatures, questions, and focus, it can be applied to a diverse variety of linguistic phenomena.

${ }^{27}$ Horn's (1972) seminal work on implicatures introduces the notion of 'scales', which are established in terms of entailment. In Horn (1989:231-232) his rationale is schematized as follows: " $P_{j}$ outranks $P_{i}$ on a given scale iff a statement containing an instance of the former unilaterally entails the corresponding statement containing the latter, $[\ldots]$ where $<\ldots, P_{j}, P_{i}, \ldots>$ indicates that $P_{j}>P_{i}$, that is, that $P_{j}$ outranks (is stronger than) $P_{i}$ on the relevant scale". Some of the examples provided by the author are:

(i) <all, most, many, some>

$<$ and, or $>$

$<$ must, should, many $>$

$<$ always, usually, often, sometimes $>$

(Horn 1989:232) 
In terms of plural morphology and semantics, which are the focus of this work, it is the application of an exhaustivity operation which produces the enriched, that is, stronger meaning and yields sentences like "Jack saw exactly one horse" (the enriched version of "Jack saw a horse"), which competes with its alternative "Jack saw horses". ${ }^{28}$ Spector (2007) offers a formal implementation of this idea, but we will not review it here. Although we assume there should be some sort of exhaustification procedure in the computational system of grammar, corresponding to alternatives being factored recursively and compositionally via $E X H$ or $O$ (see also Chierchia 2004, 2006), we will refrain from adopting a particular implementation of it. It will suffice to say that our proposal provides a way for spelling out the grammar of Kaiowá in a way that derives the behavior of bare unmarked nouns (absence of -kuera) vs. bare plural marked nouns (presence of -kuera) which relies on an implicature/alternative based approach. Other ways of dealing with phenomena of this kind in terms of implicatures are feasible. However, they are likely to share with the present approach the idea that the role of -kuera is to activate a singular semantic alternative that lacks a specialized morphological exponent that is usually marked in more familiar languages.

\section{4. -KUERA IS AN ALTERNATIVE ACTIVATOR}

We will begin this section by presenting a problem whose understanding will be crucial if the reader is to successfully follow the reasoning behind the claim that the plurality inference is a scalar implicature (SAUERLAND 2003; SPECTOR 2007; ZWEIG 2009; CHIERCHIA 2010; IVLIEVA 2013; MAYR 2015). ${ }^{29}$ Note that the sentences in (17) illustrate an asymmetry between upward vs. downward entailing environments that boils down to the following conclusion: (17b) is not equivalent to the logical negation of (17a). (17b) does not mean that at least two houses were not seen. (17b) should read that no houses, not even one, was seen (cf. Spector, 2007):

a. Upward entailing environments

She saw (the) houses.

$=$ At least two houses were seen

b. Downward entailing environments

She didn't see (the) houses.

$=$ No houses (not even one) were seen

The facts in (17) show that a model like Chierchia's (1998), in which the extension of a singular noun like 'house' is $\{a, b, c\}$ and that of its plural counterpart

${ }^{28}$ Examples in Spector (2007).

${ }^{29}$ There is also a series of studies which provide additional evidence in support of this hypothesis from the perspective of language acquisition (ROMOLI 2015; BILL et al. 2016; TIEU et al. 2020, among others). 
'houses' is $\{a+b, a+c, b+c, a+b+c\}$, with only pluralities in the extension, is flawed, because it undesirably predicts that the interpretation for (17b) is that no houses were seen, but that one house may well have been seen.

We must therefore depart from an analysis in which the plural excludes the singular from its extension in order to adopt the reasoning in which the extension of the singular noun is $\{a, b, c\}$ and that of the plural is $\{a, b, c, a+b$, $\mathrm{a}+\mathrm{c}, \mathrm{b}+\mathrm{c}, \mathrm{a}+\mathrm{b}+\mathrm{c}\}^{30}$, i.e singular-inclusive (SAUERLAND 2003; SPECTOR 2007; CHIERCHIA 2010; MAYR 2015). According to these authors' view that both singularities and pluralities must be included in the extension of the plural, it turns out that the denotation of plurals should be considered, in some sense, number neutral, mass-like, "blind" to the singular/plural distinction. Hence the problem observed in (17) is the starting point for the claim that plural nouns are semantically number neutral and that an 'at-least-two' reading is not a direct consequence of compositional semantics, and has to be derived as a scalar implicature (SPECTOR 2007; CHIERCHIA et al. 2012), ${ }^{31}$ a fact that straightforwardly accounts for unmarked plurals.

Let us now turn to the Kaiowá data: ${ }^{32}$

a. Upward entailing environments

Ha'e o-hecha oga.
3 3-see house
['S/he saw a/the house.']
'S/he saw (the) houses.'
= At least two houses were seen

b. Downward entailing environments

Ha'e nd-o-hecha-i oga(-kuera)
$3 \quad$ Neg-3-see-Neg house(-PL)
['S/he didn't see a/the house.']
'S/he didn't see (the) houses.'
= No houses (not even one) were seen

The contrast in (18) shows that both the number neutral base form and the one modified by -kuera are singular-inclusive. Our puzzle, from the beginning, has been: what is the role of -kuera? We will partially adopt Viegas' (2017) hypothesis that we are dealing with a disambiguating term, ${ }^{34}$ which is usually realized when

${ }^{30}$ In a singular-exclusive approach (Chierchia 1998), the plural would exclude $\{a, b, c\}$ from its extension.

${ }^{31}$ According to Gennaro Chierchia (p.c.), the asymmetry observed in upward vs. downward entailing environments should be regarded in itself as symptomatic of scalar implicatures.

${ }^{32}$ Irrelevant readings for the purpose of the present argumentation are between brackets.

${ }^{33}$ Only in the absence of -kuera.

${ }^{34}$ Actually, Viegas (2017) uses the term enfatizador [de coletivo] 'a collective emphasizer' as opposed to terms such as 'plural marker' or 'plural morpheme'. 
there are no other terms in the sentence or in the context that could work as cues to 'more-than-one', 'at-least-two' readings, and that piece of information is for some reason crucial or at least relevant, forcing the speaker to choose a -kueramarked noun. However, Viegas' hypothesis is presented intuitively, and it needs to be formally accounted for. In order to do so, we will assume Spector's (2007:246) neo-Gricean reasoning that

[a] speaker might prefer a given sentence A over another one B that is equivalent to A, because she is aware that B leads to pragmatic inferences that she is not ready to endorse. [Inversely,] the hearer can actually reflect on the speaker's choice of A over B, and conclude that the speaker does not believe the implicatures of $\mathrm{B}$ to be true.

Analogously, our hypothesis for Kaiowá is that the speaker's choice of a -kuera-marked nominal over a base form and vice-versa is due to the fact that $\mathrm{s}$ / he does not want their utterance to contain pieces of information s/he might not be able to endorse. Thus, both the implicature and the occurrence of the plural marker are optional, but once these optional processes come into play, triggering the activation of alternatives, scalar implicatures are obligatory (CHIERCHIA 2004; cf. CHIERCHIA (2006) for an implementation; CHIERCHIA et al. 2012; FĂLĂUŞ 2013, cf. the previous section).

An alternative based approach helps us hypothesize on the nature of number marking and plurality in this language. Quoting Fălăuş (2013:1), “the alternative linguistic forms that a speaker chooses not to use often play a significant part in the grammaticality and felicity of an utterance in a given context". The difference between Kaiowá and languages like English - and even other determinerless languages such as Hindi and Russian (cf. Dayal, 2004), which morphologically distinguish between singular and plural nouns - is that, whereas in these languages the singular form is morphologically meaningful, in Kaiowá it is not, as the base form, being number neutral, can indifferently have the singular or the plural meaning. (19a) below corresponds to the atomic reading of bare unmarked nouns, and $(19 \mathrm{~b})$ corresponds to the plural reading of bare unmarked nouns, where ' $*$, is the familiar plurality operator that closes something of type $<\mathrm{e}, \mathrm{t}>$ under sums (LINK 1983):

$$
\begin{array}{lll}
\|\operatorname{oga}\|= & \text { a. } & \lambda \mathrm{x}: \operatorname{AT}(\mathrm{x}) \cdot \operatorname{oga}(\mathrm{x}) \\
{ }^{\operatorname{house}(\mathrm{s})}, & \text { b. } & * \lambda \mathrm{x}: \operatorname{AT}(\mathrm{x}) \cdot \operatorname{oga}(\mathrm{x})
\end{array}
$$

In Heim \& Kratzer's (1998) system, these formulas should read: "choose the $\mathrm{x}$ that satisfies AT(x), then input such $\mathrm{x}$ to oga(x)". The period marks the end of the presupposition formula, so, for instance, $\lambda \mathrm{x}$ : AT(x). oga(x) presupposes AT(x) and asserts oga(x). 'AT' stands for 'atomic'. This being said, the function in (19a) applies to an individual. It is defined for an individual $\mathrm{x}$ iff $\mathrm{x}$ is an atom; whenever defined, it yields true if $\mathrm{x}$ is a house and false if it is not.

In effect, our claim is that the unmarked nouns are actually ambiguous between a mass-like, number-neutral reading (in which both singularities and pluralities are included in the extension) and a singular reading (with only singularities in the 
extension), the latter being activated only by means of the contrast triggered by -kuera. The overt plural marker, whose meaning is in (20), is the only alternative activator in the number system of the language:

\section{(20) $\|$ kuera $\|=\lambda \mathrm{P}: * \mathrm{P}=\mathrm{P} . \mathrm{P}$}

The function in (20) is the pluralizing function. Formally, it is a partial identity map ${ }^{35}$ over things of type $<\mathrm{e}, \mathrm{t}>$. Applied to a property $\mathrm{Q}$ it checks whether closing it under sum returns Q (which means that Q is already closed under sum) or something different. If Q is closed under sum, we get $\mathrm{Q}$ back. If Q is not closed under sum, we get 'error' (meaning that the function returns undefined). Thus, for example:

(21) a. $\quad \|$ kuera $\|(\lambda x: \operatorname{AT}(x) . \operatorname{oga}(x))=$ undefined, because $* \lambda x: \operatorname{AT}(x) . \operatorname{oga}(x) \neq \lambda x$ : $\operatorname{AT}(x) \cdot \operatorname{oga}(x)$

While:

b. $\quad \|$ kuera $\|(* \lambda x$ : AT(x), oga $(x))=* \lambda x$ : AT(x), oga $(x))$, because obviously $* \lambda x$ : $\operatorname{AT}(x) \cdot \operatorname{oga}(x)=\lambda x: \operatorname{AT}(x) \cdot \operatorname{oga}(x)$

We argue that the singular function is not morphologically available in the language, being activated only semantically, as an alternative of -kuera. The singular meaning is what gives us the right alternative, that is, the right competitor to derive the 'at-least-two' reading of the overt plural marker. The two competing readings, separated by a comma, constitute the set of scalar alternatives in (22):

$$
\text { kuera }^{\mathrm{ALT}}=\{\lambda \mathrm{P}: * \mathrm{P}=\mathrm{P} . \mathrm{P}, \lambda \mathrm{P}: \mathrm{AT}(\mathrm{P})=\mathrm{P} . \mathrm{P}\}
$$

$\lambda \mathrm{P}: \mathrm{AT}(\mathrm{P})=\mathrm{P} . \mathrm{P}$ is a good candidate to represent singular marking. It yields the reverse of the plural marking, i.e., it is only defined for (19a), not for (19b), as the following computation shows:

a. $\quad \lambda P: \operatorname{AT}(P)=P \cdot P(\lambda x: \operatorname{AT}(x) \cdot \operatorname{oga}(x))=\lambda x: \operatorname{AT}(x) \cdot \operatorname{oga}(x)$, because $\operatorname{AT}(\lambda x: \operatorname{AT}(x)$. $\operatorname{oga}(\mathrm{x}))=\lambda \mathrm{x}: \mathrm{AT}(\mathrm{x}) \cdot \operatorname{oga}(\mathrm{x})[$ since $\lambda \mathrm{P}: \mathrm{AT}(\mathrm{P})=\operatorname{oga}(\mathrm{x})$ obviously contains only atoms]

While

b. $\quad \lambda P: \operatorname{AT}(\mathrm{P})=$ P.P $(* \lambda x: \operatorname{AT}(x)$. oga $(x))=$ undefined, because obviously $* \lambda x$ : $\operatorname{AT}(x) \cdot \operatorname{oga}(x) \neq \lambda x: \operatorname{AT}(x) \cdot \operatorname{oga}(x)$

-kuera, being a function of type $<<\mathrm{e}, \mathrm{t}><\mathrm{e}, \mathrm{t}>>$, typical of plural marking, can only combine with (19b), a sum.

${ }^{35}$ A partial identity map is a function that maps only certain objects into themselves. 


\section{SOME LOOSE ENDS AND PERSPECTIVES: -KUERA AS AN ASSOCIATIVE PLURAL MARKER}

As we have claimed, -kuera behaves like an ordinary plural marker, which makes it part of the core number system of the language. Nevertheless, as we were finishing our data collection, we also observed that in some contexts it can function as an associative plural marker. In the first case its presence is optional; in the second, it is obligatory:
a. Kunã (-guera/-kuera)
o-ho o-johei ijao ygua-pe. woman(-PL)
3-go 3-wash cloth pond-Loc

'The woman/women went to the pond to wash clothes.'

b. Maria-kuera o-ho o-johei ijao ygua-pe.

Maria-PL 3-go 3-wash cloth pond-Loc

'Maria and her family or friends or associates went to the pond to wash clothes.'

A test with negation, taken from Dayal (2014 apud BISWAS 2014) may help us sort out the two distinct environments. While bare plurals (optionally modified by -kuera) displaying ordinary plural readings have narrow scope in the presence of a negative operator, associative plural readings (obligatorily modified by -kuera) have wide scope:

$$
\begin{aligned}
& \text { a. Mbo'ehara(-kuera) nd-o-iko-i ape. } \\
& \text { teacher(-PL) Neg-3-be-Neg here }
\end{aligned}
$$

[A situation in which no teacher has been hired or in which all of them have been fired]

b. Mbo'ehara-kuera nd-o-iko-i ape.

teacher-PL Neg-3-be-Neg here

'The teachers are not here.'

[A situation in which the teachers/the faculty took a day off]

It goes without saying that we are dealing here with an important contrast which deserves further verification. In any case, from a typological point of view, we can preliminarily conclude that Kaiowá, differently from other languages, like Bangla and Japanese, just to name a few, makes use of the same morpheme in order to express both ordinary and associative plurals. 


\section{FINAL REMARKS}

This paper discussed the Kaiowá noun phrase as far as the expression of number and (in)definiteness are concerned. We laid out our data in order to show that the occurrence of -kuera, an optional plural marker, is not restricted to definite environments. This observation led us to conclude that Kaiowá behaves differently from other languages which display (apparently) optional number marking. We believe ourselves to have solved the puzzle concerning the nature of -kuera: taking into account that the bare noun is fully amenable to a plural interpretation, why is this morpheme even available in the language? We have showed that its role is that of an alternative activator. Our proposal is that it semantically activates a singular function and, conversely, this is what yields the right alternative to derive, by implicature, the 'at-least-two' reading of the overt plural marker.

\section{REFERENCES}

ALVES, Flávia de C. O Timbira falado pelos Canela Apãniekrá: uma contribuição aos estudos da morfossintaxe de uma língua Jê. PhD dissertation. Campinas: Universidade Estadual de Campinas, 2004.

BILL, Cory; ROMOLI, Jacopo; SCHWARZ, Florian; CRAIN, Stephen. Scalar implicatures vs. presuppositions - the view from acquisition. Topoi, v. 35, 2006, p. 57-71.

BISWAS, Priyanka. Bangla Associative Plural -ra: a crosslinguistic comparison with Chinese men and Japanese -tachi. In: SANTANA-LABARGE, Robert E. (ed.), Proceedings of the $31^{\text {st }}$ West Coast Conference on Formal Linguistics, p. 56-65. Somerville, MA: Cascadilla Proceedings Project, 2014.

BUTLER, Nancy E. The multilple functions of the definite article in Terena. Série Linguística, SIL, 2003. Available at https://www.silbrasil.org.br/resources/archives/16965. Access on 11 August, 2020.

CARDOSO, Valéria F. Aspectos Morfossintáticos da Lingua Kaiowá (Guarani). PhD dissertation. Campinas: Universidade Estadual de Campinas, 2008.

CARLSON, Gregory. Reference to kinds in English. PhD dissertation. University of Massachusetts, Amherst, 1980. Available at https://scholarworks.umass.edu/dissertations/AAI7726414. Access on 20 July, 2020.

CARVALHO, Rosileide. Análise Morfológica da Língua Kaiowá: fundamentos para uma gramática e dicionário bilíngue. MA thesis. Brasília: Universidade de Brasília, 2017.

CHACON, Thiago C. O lugar das partículas entre palavras, morfemas e sintagmas em Kubeo. Boletim do Museu Paraense Emílio Goeldi. Ciências Humanas, 2019, v. 14, n. 3, p. 767-790.

CHIERCHIA, Gennaro. Reference to kinds across languages. Natural Language Semantics, v. 6, 1998b, p. 339-405. 
CHIERCHIA, Gennaro. Scalar implicatures, polarity phenomena, and the syntax/pragmatics interface. In: BELLETTI, Adriana (ed.). Structures and Beyond, v. 3, Oxford: Oxford University Press, 2004, p. 39-103.

CHIERCHIA, Gennaro. Broaden Your Views: Implicatures of Domain Widening and the Logicality of Language. Linguistic Inquiry, v. 37, n. 4, 2006, p. 535-590.

CHIERCHIA, Gennaro. Mass nouns, vagueness and semantic variation. Synthese, v. 174, 2010, p. 99-149.

CHIERCHIA, Gennaro; FOX, Danny; SPECTOR, Benjamin. Scalar implicature as a grammatical phenomenon. In: VON HEUSINGER, Klaus; MAIENBORN, Claudia; PORTNER, Paul (eds.), Semantics: an international handbook of natural language meaning, v. 3, p. 2297-2331. Berlin: De Gruyter, 2012.

CHOMSKY, Noam. Linguagem e Mente: pensamentos atuais sobre antigos problemas. Trad. Lucia Lobato. Brasília: Editora UnB, 1998.

CHOMSKY, Noam. Beyond Explanatory Adequacy. In: BELLETTI, Adriana (ed.), The cartography of syntactic structures: structures and beyond v. 3, p. 104-131. Oxford: Oxford University Press, 2004 [2001].

CHOMSKY, Noam; LASNIK, Howard. The Theory of Principles and Parameters. In: CHOMSKY, Noam. The Minimalist Program. Cambridge, Mass.: The MIT Press, 1995, p. 13-127.

CORBETT, Greville. Number. Cambridge University Press, 2000.

CYRINO, Sônia; ESPINAL, M. Teresa. Bare Nominals in Brazilian Portuguese: more on the DP/NP analysis. Natural Language and Linguistic Theory, v. 33, n. 2, 2014, p. 471-521.

DAYAL, Veneeta. Number marking and (in)definiteness in kind terms. Linguistics and Philosophy, v. 27, 2004, p. 393-450.

DAYAL, Veneeta. Identifying (in)definiteness: a questionnaire. In Veneeta Dayal (org.), A hitchhiker's guide to (in)definiteness: case studies in languages without articles (in press).

DIETRICH, Wolf. La función del sufijo Guaraní -kue/-(n)gue. 2011. Available at www.researchgate. net/publication/309761428. Access on 15 June, 2019.

DORON, Edit; MÜLLER, Ana. The cognitive basis of mass-count distinction: evidence from bare nouns. In: CABREDO HOFHERR, Patricia; ZRIBI-HERTZ, Anne (eds.). Syntax \& Semantics: crosslinguistic studies on noun phrase structure and reference, p. 73-101, 2014.

DRYER, Matthew S. Indefinite articles. In: DRYER, Matthew S.; HASPELMATH, Martin (eds.). The World Atlas of Language Structures Online. Leipzig: Max Planck Institute for Evolutionary Anthropology, 2013. Available at http://wals.info/chapter/38. Access on 24 april, 2020.

FĂLĂUŞ, Anamaria. Alternatives in semantics. London: Palgrave Macmillan, 2013.

GAZDAR, Gerald. Pragmatics: implicature, presupposition and logical form. New York: Academic Press, 1979. 
GIVÓN, Talmy. Topic, pronoun and grammatical agreement. In: LI, Charles (ed.). Subject and Topic. New York: Academic Press, 1976, p. 151-188.

GIVÓN, Talmy. On the development of the numeral 'one' as an indefinite marker. Folia Linguistica Historica, v. 2, n. 1, 1981, p. 35-53.

GOMES, Dioney M. Partículas em Mundurukú (Tupí). Boletim do Museu Paraense Emílio Goeldi. Ciências Humanas, 2019, v. 14, n. 3, p. 717-720.

GRICE, H. Paul. Logic and conversation. In COLE, Peter; MORGAN, Jerry L. (eds.). Syntax and Semantics 3: speech acts. New York: Academic Press, 1975, p. 41-58.

GUERRA VICENTE, Helena; SANCHEZ-MENDES, Luciana; PIRES DE OLIVEIRA, Roberta; LUNGUINHO, Marcus V.; LEANDRO-SPRINGER, Wendy. The nominal system in Wapishana (Aruák), preliminar results. Linguistic Variation, v. 20, n. 2, 2020, p. 397-407.

HEIM, Irene; KRATZER, Angelika. Semantics in generative grammar. Malden, MA: Blackwell, 1998.

HORN, Laurence R. On the semantic properties of logical operators in English. PhD dissertation. University of California, Los Angeles, 1972. Available at https://linguistics.ucla.edu/images/ stories/Horn.1972.pdf. Access on 03 July, 2020.

HORN, Laurence R. A natural history of negation. Chicago: Chicago University Press, 1989.

IVLIEVA, Natalia. Scalar implicatures and the grammar of plurality and disjunction. $\mathrm{PhD}$ dissertation. Cambridge, Mass.: Massachusetts Institute of Technology, 2013.

JIANG, Li Julie. Mandarin associative plural -men and NPs with -men. International Journal of Chinese Linguistics, v. 4, n. 2, 2017, p. 191-256.

LINK, Godehard. The logical analysis of plurals and mass terms: a lattice-theoretic approach. In PORTNER, Paul; PARTEE, Barbara (eds.). Formal semantics: the essential readings. Blackwell, 1983, p. 127-147.

LYONS, Christopher. Definiteness. Cambridge, UK: Cambridge University Press, 1999.

MAGALHÃES, Marina. Sobre a morfologia e a sintaxe da lingua Guajá. PhD dissertation. Brasília: Universidade de Brasília, 2008.

MAGALHÃES, Marina. A gramaticalização de verbos em partículas na língua Guajá e sua relação com a omnipredicatividade. Boletim do Museu Paraense Emílio Goeldi. Ciências Humanas, 2019 , v. 14 , n. 3, p. $897-918$.

MAGALHÃES, Marina; SILVA, Léia. Estudos sobre partículas. Boletim do Museu Paraense Emílio Goeldi. Ciências Humanas, 2019, v. 14, n. 3, p. 717-720.

MATO GROSSO DO SUL. Secretaria Estadual de Educação (SED/MS). Ne 'e Poty Kuemi: mbo'ehára kuera Kaiowá ha Guarani - Projeto Ára Verá ('espaço-tempo iluminado'/ 'bright space-time'). Campo Grande: Agiosul, 2002.

MATTHEWSON, Lisa. Quantification and the nature of crosslinguistic variation. Natural Language Semantics, v. 9, 2001, p. 145-189. 
MAYR, Clemens. Plural Definite NPs Presuppose Multiplicity Via Embedded Exhaustification. Proceedings of SALT 25, 2015, p. 204-224.

MEJIA, Blanca Flor. Verbos em Kaiowá: uma descrição morfológica. MA thesis. Dourados-MS. Universidade Federal da Grande Dourados, 2017.

MÜLLER, Ana. Nomes nus e o parâmetro nominal no português brasileiro. Revista Letras, v. 58, p. 331-344.

MÜLLER, Ana; OLIVEIRA, Fátima. Bare Nominals and Number in Brazilian and European Portuguese. Journal of Portuguese Linguistics, v. 3, n. 1, 2004, p. 9-36.

MÜLLER, Ana; STORTO, Luciana; COUTINHO-SILVA, Thiago. Número e a distinção contávelmassivo em Karitiana. Revista da ABRALIN, v. 5, n. 1 e 2, 2006, p. 185-213.

PIRES DE OLIVEIRA, Roberta. O plural no português brasileiro e no inglês: comparando através das línguas. Caderno de Squibs: temas em estudos formais da linguagem, v. 5, n. 1, 2019, p. 15-24.

PIRES DE OLIVEIRA, Roberta; ROTHSTEIN, Susan. Two sorts of bare nouns in Brazilian Portuguese. Revista ABRALIN, v. 10, n. 3, 2011, p. 231-266.

PRAÇA, Walkiria N. Morfossintaxe da língua Tapirapé. PhD dissertation. Brasília: Universidade de Brasília, 2007.

QUEIXALÓS, Francesc. Partículas em Sikuani. Boletim do Museu Paraense Emílio Goeldi. Ciências Humanas, 2019, v. 14, n. 3, p. 721-738.

RAMIRES, Daiane; GUERRA VICENTE, Helena. Sintagmas nominais do Kaiowá (Tupí-Guaraní): expressão de número e (in)definitude. Caderno de Squibs, v. 4, n. 1, 2018, p. 59-72.

RAMIRES, Daiane. Sintagmas nominais no Kaiowá: expressão de número e (in)definitude. MA thesis. Brasília: Universidade de Brasília, 2019.

RODRIGUES, Aryon. Linguas brasileiras: para o conhecimento das línguas indígenas. São Paulo: Loyola, 1985.

ROMOLI, Jacopo. An experimental comparison between presuppositions and indirect scalar implicatures. In: SCHWARZ, Florian (ed.). Experimental perspectives on presuppositions. Springer International, 2015, p. 215-240.

SANCHEZ-MENDES, Luciana; QUADROS GOMES, Ana P.; JULIO, Aronaldo. The count-mass distinction in Terena. Linguistic Variation, v. 20, n. 2, 2020, p. 381-396.

SANTOS, Manoel. 2006. Uma gramática do Wapixana (Aruák) - aspectos da fonologia, da morfologia e da sintaxe. $\mathrm{PhD}$ dissertation. Campinas-SP: Universidade Estadual de Campinas.

SAUERLAND, Uli. A new semantics for number. In: YOUNG, Robert B.; ZHOU, Yuping (eds.), Proceedings of SALT 13, p. 258-275. Ithaca, NY: CLC Publications, Cornell University, 2003.

SAUERLAND, Uli. Scalar implicatures in complex sentences. Linguistics and Philosophy, v. 27, 2004, p. 367-391. 
SPECTOR, Benjamin. Aspects of the pragmatics of plural morphology: on higher-order implicatures. In: SAUERLAND, Uli; STATEVA, Penka (eds.), Presupposition and Implicature in Compositional Semantics. UK: Palgrave Macmillan, 2007, 243-281.

TIEU, Lyn; BILL, Corry; ROMOLI, Jacopo; CRAIN, Stephen. Testing theories of plural meanings: insights from child language. Cognition, 2000. Available at https://semanticsarchive.net/ Archive/jE1NDFkY/TBRC_AcqPlurals.pdf. Access on 21 July, 2020.

VIEGAS, Lívia. Nomes e predicados nominais em Kaiowá. MA thesis. Dourados-MS: Universidade Federal da Grande Dourados, 2017.

VON FINTEL, Kai; MATTHEWSON, Lisa. Universals in semantics. The Linguistic Review, v. 25, 2008, p. 139-201.

ZWEIG, Eytan. Number neutral bare plurals and the multiplicity agreement. Linguistics and Philosophy, v. 32, 2009, p. 353-407.

Recebido: 17/3/2020

Aceito: 30/6/2020

Publicado: 14/8/2020 